\title{
Gap junctions in cells of the immune system: structure, regulation and possible functional roles
}

J.C. Sáez, M.C. Brañes, L.A. Corvalán, E.A. Eugenín, H. González, A.D. Martínez and F. Palisson

\author{
Departamento de Ciencias Fisiológicas, \\ Pontificia Universidad Católica de Chile, Santiago, Chile
}

\author{
Correspondence \\ J.C. Sáez \\ Departamento de Ciencias \\ Fisiológicas \\ Pontificia Universidad Católica \\ de Chile \\ Alameda 340 \\ Santiago \\ Chile \\ Fax: + 56-2-222-5515 \\ E-mail: jsaez@genes.bio.puc.cl \\ Presented at the Meeting \\ "Gap Junctions in the Nervous and \\ Cardiovascular Systems: Clinical \\ Implications", Rio de Janeiro, RJ, \\ Brazil, June 6-11, 1998. \\ J.C. Sáez, M.C. Brañes, E.A. Eugenín, \\ A.D. Martínez, and F. Palisson are \\ recipients of FO NDECYT grants (Nos. \\ 1990146, 2960002, 2960001, \\ 2990004 and 2990089, respectively).
}

Received August 3, 1999

Accepted September 29, 1999

\section{Abstract}

Gap junction channels are sites of cytoplasmic communication between contacting cells. In vertebrates, they consist of protein subunits denoted connexins (Cxs) which are encoded by a gene family. According to their $\mathrm{Cx}$ composition, gap junction channels show different gating and permeability properties that define which ions and small molecules permeate them. Differences in $\mathrm{Cx}$ primary sequences suggest that channels composed of different Cxs are regulated differentially by intracellular pathways under specific physiological conditions. Functional roles of gap junction channels could be defined by the relative importance of permeant substances, resulting in coordination of electrical and/or metabolic cellular responses. Cells of the native and specific immune systems establish transient homo- and heterocellular contacts at various steps of the immune response. Morphological and functional studies reported during the last three decades have revealed that many intercellular contacts between cells in the immune response present gap junctions or "gap junction-like" structures. Partial characterization of the molecular composition of some of these plasma membrane structures and regulatory mechanisms that control them have been published recently. Studies designed to elucidate their physiological roles suggest that they might permit coordination of cellular events which favor the effective and timely response of the immune system.

\section{Introduction}

Numerous reports have described different mechanisms for intercellular communication between members of the immune system, including cell adhesion molecules, membrane molecules that act as ligand-receptors (1) and soluble molecules secreted into the extracellular milieu which act as paracrine and autocrine signals (2). In contrast, little attention has been given to gap junction in-

\section{Key words}

- Cell contacts

- Gap junctions

- Connexins

- Native immune response

- Specific immune response

- Inflammatory response tercellular communication. Recently, two reviews have described gap junction communication between cells of the immune system $(3,4)$. The present article attempts to provide an updated and brief review on gap junctions expressed by different cellular members of native and specific immune systems.

Gap junctions have recently been reviewed (5). Briefly, gap junction channels span the plasma membrane of two adjacent 
cells and each cell contributes one half of the channel, called connexon. Each hemichannel consists of the oligomers of six protein subunits termed connexins (Cxs). A gene family of which at least 14 different homologous members have been identified in rodents encodes these proteins. Cxs are named according to their molecular mass predicted from their cloned DNA sequence. Most cells, excluding vertebrate skeletal muscle, red blood cells and spermatozoids, form gap junctions and express two or more $\mathrm{Cx}$ types. Cells of invertebrate organisms express functionally equivalent channels, but their protein subunits are not members of the $\mathrm{Cx}$ family (6). In recent reports, it has been shown that gap junction channels and hemichannels can result from the interaction of two different Cxs (5). Moreover, numerous reports have shown that gap junction communication can be regulated at various cellular levels, including mRNA transcription, mRNA stability and channel gating (5). Gap junction channels formed by different $\mathrm{Cx}$ types present different gating and permeability properties that fulfill different functions and thus are adjusted to the various regulatory mechanisms present in each cell type and under different physiological conditions.

The first descriptions of electrical coupling between activated lymphocytes were reported in the early 1970's (7-9). Further evidence of gap junctional communication, including transfer of fluorescent dyes, metabolic cooperativity and electron microscopy studies (thin sections and freeze fracture replicas), reported at that time have been recently reviewed $(3,4)$. The homocellular gap junctional communication at cell-cell contacts between other members of the immune system, such as macrophages $(10,11)$, follicular dendritic cells (12), thymic epithelial cells (13), polymorphonuclear (PMN) cells $(14,15)$ and microglia $(16)$ has also been reported. In addition, it has been shown that heterocellular contacts between macro- phages and neutrophils (17), and leukemia cells and myeloid sinus endothelium (18) contain gap junctions. Similarly, "gap junction-like" structures as heterocellular contacts between Langerhans cells and T-cells (4,19-21), lymphocytes and endothelial cells (22) and PMN cells and endothelial cells (14) have been described. Moreover, heterocellular gap junctional communication between lymphocytes and endothelial cells (23), thymocytes and thymic epithelial cells (13), macrophages and epithelial cells (24-26), mastocytoma cells and lymphocytes (27) and follicular dendritic cells and B-cells (28) has also been reported.

\section{Gap junctions in the bone marrow and secondary lymphoid organs}

Both in vivo (29) and in vitro $(30,31)$ studies have demonstrated that bone marrow stromal cells form gap junctions. Morphological and functional studies have also shown gap junctions between bone marrow stromal cells as well as between stromal and hematopoietic progenitor cells $(28,32-35)$. In primary cultures of bone marrow, the extent of dye transfer between cells increases progressively with time in culture (35), suggesting that in vitro cells are free from the environmental factors present in vivo that restrain the functional expression of gap junction. Consistently, the reduction in hematopoietic tissue induced with fluorouracil is followed by a dramatic increase in the number of gap junctions between bone marrow cells and the number falls back to the normal values before the bone is filled with marrow (36).

Stromal cells do not express Cxs 26 and 32 and communicate with each other through gap junctions that contain $\mathrm{Cx} 43(31,37)$. It is not known whether stromal cells and hematopoietic progenitor cells express other Cxs, as described for most cells of other systems (5). Treatment with interleukin-1 or TNF- $\alpha$ (37), but not irradiation (30), reduces 
gap junctional communication between stromal cells. Similarly, differentiation of stromal cells to adipocytes is associated with a reduction in gap junctional communication (30) and $\mathrm{Cx} 43$ reactivity (31). Gap junctions are more abundant in hematopoietic stem cells before growth (36) and in cells of different types of leukemias that present an increased stromal:hematopoietic cell ratio (37). Megakaryocytes present in normal bone marrow contain $\mathrm{Cx} 43$, but not $\mathrm{Cx} 26$ or $\mathrm{Cx} 32$ (38). During migration, gap junction-like structures have been identified between neutrophils or lymphocytes and cells of the sinusoidal wall (adventitial or endothelial cells) of the bone marrow (39).

The first report of gap junction formation between follicular dendritic cells showed that these cells express $\mathrm{Cx} 43$, but not $\mathrm{Cx} 32$ or Cx26 (12). Recently, this analysis has been extended showing that they also contain Cx37 (4). In mouse lymph nodes, both Cxs 37 and 43, but not Cxs 26, 32, 33, 45 or 50 , are present in follicular dendritic cells, interdigitating cells, T-cells and B-cells $(4,40)$. At least the reactivity to $\mathrm{Cx} 43$ in follicular dendritic cells is inducible. These Cxs are frequently detected at cell-cell contacts, suggesting that they form functional channels. In agreement, dye transfer between cultured human dendritic cells and B lymphocytes has been shown (28). Gap junctions found at heterocellular contacts might be relevant in the diverse events of the immune response that occur within lymph nodes, including antigen presentation and lymphocyte proliferation.

Carolan and Pitts (41) have shown metabolic coupling between thymocytes, suggesting that they establish gap junctional communication. This possibility was recently supported by the demonstration of electrical coupling and dye transfer between these cells and blockade of intercellular communication with octanol, a conventional gap junction blocker (13). In addition, thymic epithelial cells and thymocytes communicate with each other through gap junctions that contain at least $\mathrm{Cx} 43$ (13). In cultured thymic epithelial cells a significant amount of $\mathrm{Cx} 43$ is phosphorylated and cells are well coupled (13).

\section{Gap junctions in the native immune system}

The main cell components of the native immune system are cell barriers (endothelia and epithelia), granulocytes, monocytes/macrophages, and natural killer cells. All endothelial and epithelial cells studied express Cxs. Both cell types frequently retain $\mathrm{Cx}$ expression and gap junction communication in primary cultures (Figure 1). Exposure to inflammatory mediators reduces gap junction communication between cultured endothelial cells. TNF- $\alpha$ and interleukin-1 reduce dye coupling between human umbilical vein endothelial cells (HUVECs) $(42,43)$. The effect of TNF- $\alpha$ on the expression of Cxs by HUVEC is differential; while Cxs 37 and 40 are reduced, $\mathrm{Cx} 43$ remains unchanged (43). Moreover, histamine reduces gap junction communication between high vascular endothelial cells isolated from human tonsils (Figure 1). In myoendothelial preparations treated with lipopolysaccharides (LPS), TNF- $\alpha$, or IL-1 $1 \beta$, homocellular coupling remains unchanged but the heterocellular coupling is drastically reduced (44). Similarly, the heterocellular coupling between rat brain endothelial cells and astrocytes is transiently reduced by TNF- $\alpha$ (45).

Ultrastructural and functional evidence indicates that migratory leukocytes found at inflammatory foci form gap junction-like structures with the endothelial cells of the microcirculation. After ischemia-reperfusion (14) or during the initial stage of autoimmune demyelinization (22), specific subsets of circulating leukocytes (neutrophils and lymphocytes, respectively) form "gap junction-like" structures with the endothelium. Moreover, bidirectional dye (calcein) trans- 
fer between lymphocytes and endothelial cells (23) or macrophages P388D1 and IEC6 epithelial cells has been demonstrated (2426). In the latter system, gap junction-dependent propagation of $\mathrm{Ca}^{2+}$ waves in response to mechanical stimulation has also been shown (25), suggesting that these two cell types perform coordinated activities and/ or one regulates the state of the other through
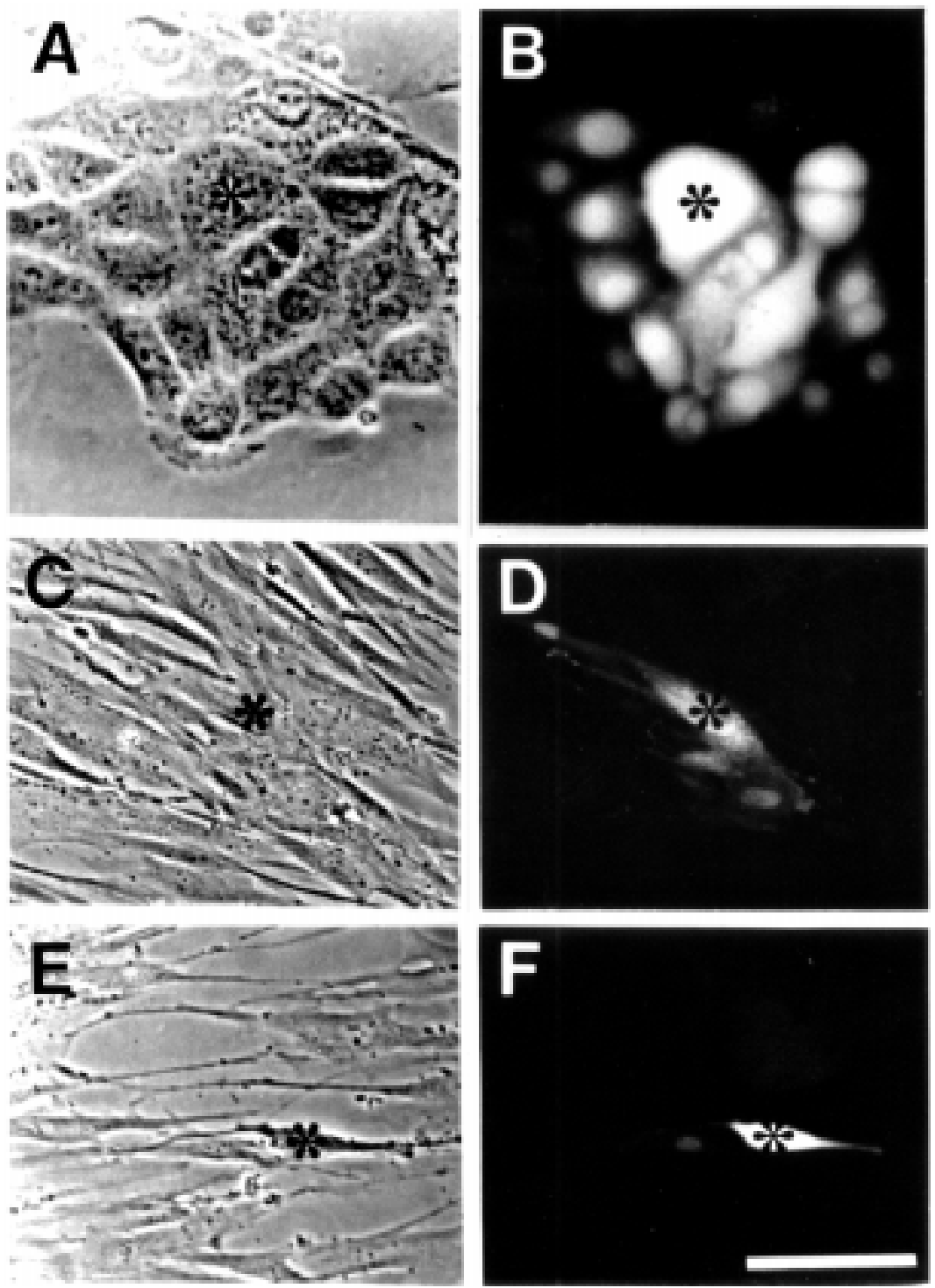

Figure 1 - Dye coupling between epithelial or endothelial cells. Dye coupling tested by microinjecting Lucifer yellow-CH into one cell and observing its spreading to adjacent cells is found in a subconfluent culture of MDCK cells (B) and a confluent culture of high vascular endothelial cells isolated from human tonsils (D). Dye coupling is drastically reduced $(F)$ in high vascular endothelial cells treated for $1 \mathrm{~h}$ with $0.1 \mu \mathrm{M}$ histamine. $\mathrm{A}, \mathrm{C}$ and $\mathrm{E}$ are phase contrast views of the fluorescent fields shown in B, D and F, respectively. Bar: $100 \mu \mathrm{m}$. a $\mathrm{Ca}^{2+}$-dependent mechanism mediated by gap junctions. Polarity of dye movement has been found in studies of gap junction permeability between smooth muscle and endothelial cells of hamster cheek pouch arterioles (46), suggesting the existence of a directional preference for diffusion of intercellular signals and/or metabolites. It is not known whether gap junctions formed between leukocytes and cellular barriers show unidirectional permeability preferences.

In vertebrates, the main blood cell members of the native immune response are PMN cells of which the most abundant are neutrophils. Available information indicates that the expression of Cxs in these cells is inducible. Activated human PMN cells form homocellular gap junctions in vitro (15). Moreover, circulating hamster leukocytes do not express $\mathrm{Cx} 43$ and after incubation with LPS for $1 \mathrm{~h}$ they become reactive to antiCx43 antibodies (Figure 2) (14), suggesting that the expression of this protein is inducible. In addition, the application of platelet activating factor (PAF) to the hamster cheek pouch induces recruitment and firm adhesion of $\mathrm{Cx} 43$ positive PMN cells to the endothelium of the microcirculation, but fails to induce the expression of $\mathrm{Cx} 43$ in isolated leukocytes (47), indicating that PAF-induced Cx43 expression observed in vivo might not result from the direct PAF-hamster leukocyte interaction. Similarly, LPS induces formation of human PMN aggregates and translocation of $\mathrm{Cx} 43$ towards the plasma membrane, but cells remain dye uncoupled. Nevertheless, LPS-activated PMN cells in medium conditioned by rat brain endothelial cells treated with LPS develop prominent dye coupling (15).

Depending on the circulatory region, endothelial cells express $\mathrm{Cx} 43$ and $\mathrm{Cx} 40$ and/ or Cx37 (5). Since these Cxs form gap junctions with different permeability and gating properties (5), differences in Cx composition of the homocellular (endothelial cellendothelial cell) and heterocellular (endo- 
thelial cell-smooth muscle cell) gap junctions formed might explain the dye movement polarity found in hamster cheek pouch arterioles (46). During an inflammatory response, endothelial cells also form gap junctions with activated leukocytes (14), suggesting that endothelial Cxs are sorted to the apical membrane to form gap junction channels with compatible leukocyte Cxs.

Connective tissues contain a variety of cells with defense and immune functions, such as tissue macrophages and mast cells. The first demonstrations of gap junctional communication between cultured canine and murine macrophage cells were reported two decades ago $(10,11)$. But, it was only during the last decade that $\mathrm{Cx} 43$ was detected in several macrophage types, including the murine cell line J774 (48), macrophage foam cells from arteriosclerotic lesions (49), peritoneal macrophages (14), kidney macrophages in inflammatory renal disease (50), Kupffer cells (51), microglia (16) and Langerhans cells (4). Cx43 mRNA has been detected in cultured monocytes/macrophages (52), but not in freshly isolated human monocytes/ macrophages (49). Moreover, it has been recently reported that mast cells express Cxs 32 and 43, but not $\mathrm{Cx} 26$ (53).

J774 macrophages (54), human monocytes/macrophages or HUVECs and monocytes/macrophages (49) do not establish intercellular communication in culture. Nevertheless, P388D1 or J744 macrophages cocultured with epithelial cell lines show homocellular dye coupling, as well as heterocellular dye coupling with epithelial cell lines (25), suggesting that soluble factors present in the co-culture induce macrophages to form gap junctions. In support of this possibility, culture medium conditioned with endothelial cells derived from rat brain microcirculation induces dye coupling (Figure 3 ) and translocation of Cxs from the cytoplasmic compartment to the plasma membrane in J774 cells (Eugenín EA, Garcés G and Sáez JC, unpublished observation). Mi- croglia, the main immune effector of the central nervous system, also become dye coupled when cultured for a few hours in medium conditioned by rat brain endothelial cells (Eugenín EA, Martínez AD and Sáez JC, unpublished observation). Dye coupling between microglia is also observed after 49-h treatment with a calcium ionophore (16) (Figure 3), suggesting that activated macrophages can establish gap junctional communication.

Structural and functional studies have demonstrated cell junctions equivalent to gap junctions between invertebrate blood cells (hemocytes) (55). These cells establish functional intercellular communication within seconds when they are pushed together (55), suggesting that hemocytes present a preformed pool of hemichannels for
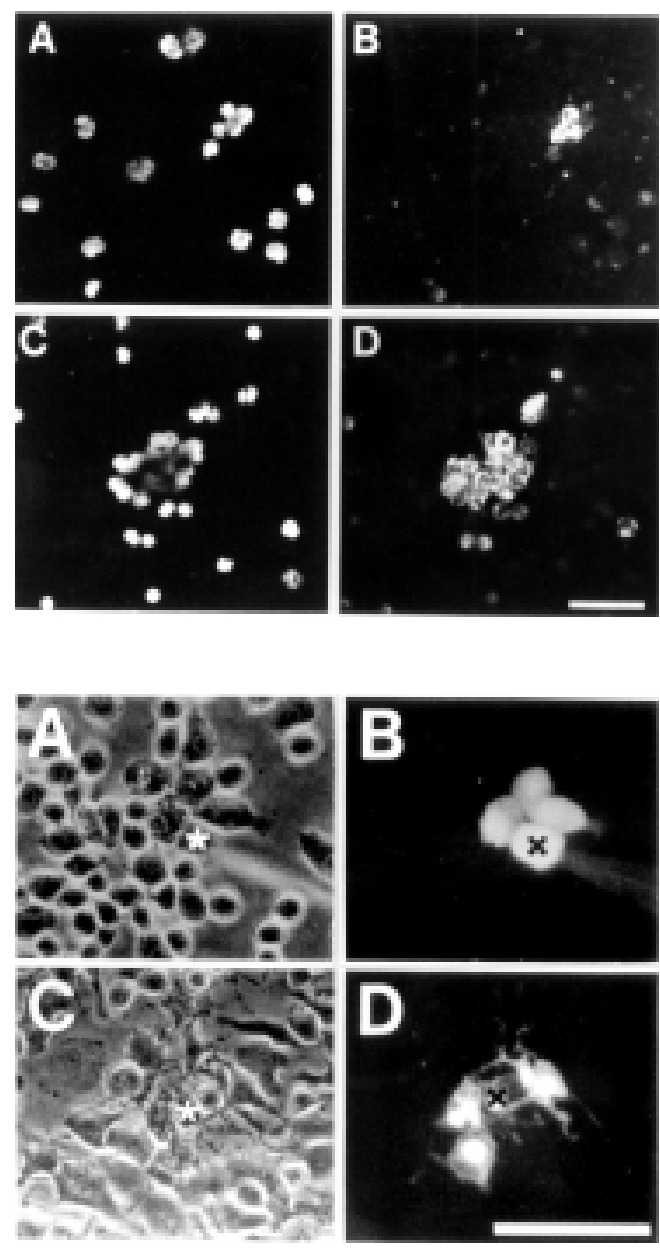

Figure $2-\mathrm{C} \times 43$ is not found in circulating PMN cells and its expression is induced by LPS. Most freshly isolated hamster leukocytes incubated for $3 \mathrm{~h}$ at $37^{\circ} \mathrm{C}$ in culture medium containing 5\% FBS remained as singlet cells and very few were immunoreactive to $\mathrm{Cx} 43$ (B). Nonetheless, cells treated with $1 \mathrm{mg} / \mathrm{ml}$ LPS for $3 \mathrm{~h}$ formed many aggregates and were immunoreactive to Cx43 (D). In each situation the cells shown in (B) and (D) were identified by their nuclear staining with DAPI in A and C, respectively. Bar: $75 \mu \mathrm{m}$.

Figure 3 - Induction of dye coupling between macrophage cells. In cultures of (B) rat microglia treated for $3 \mathrm{~h}$ with the calcium ionophore 8Br-A23187 (2 $\mu \mathrm{M}$ ) or (D) murine macrophages (J 774) treated for $3 \mathrm{~h}$ with medium conditioned for $24 \mathrm{~h}$ by rat brain endothelial cells there was dye transfer to several neighboring cells. $A$ and $D$ are phase contrast views of the fluorescent fields shown in $B$ and $D$, respectively. Bar: $120 \mu \mathrm{m}$. 
ready formation of intercellular channels. The structural components of these channels remain unknown, but it is likely that they are proteins homologous to those described to form intercellular channels in Drosophila melanogaster and C. elegans, termed innexins (6).

\section{Gap junctions between cells of the specific immune system}

Activation of a specific immune response requires a direct physical interaction between antigen-presenting cells and T-cells, the main cellular effector of the specific immune system (1). At Langerhans and T-cell interphases, gap junction-like structures have been identified both in vitro $(19,20)$ and in vivo (21). At cell-cell contacts between cultured Langerhans cells and T-cells, at least $\mathrm{Cx} 43$ is detected (4). The formation of gap junction channels requires a cell-cell proximity mediated by cell adhesion molecules (5). Thus, the anti-vascular cell adhesion molecule-1 (VCAM-1) antibody-induced inhibition of the lymphocyte proliferative response in the allogeneic mixed lymphocyte reaction (56) might be the consequence, at least in part, of the blockade of a gap junction-dependent mechanism.

Lymphocytes (T-cells plus B-cells or just T-cells) treated with either concanavalin A (Con-A) or phytohemagglutinin (PHA) form clusters of variable sizes. Circulating human or bovine lymphocytes treated with PHA express a low resistance pathway that allows the intercellular transfer of electrical stimuli $(7,8)$. Moreover, intercellular transfer of fluorescein or radiolabeled uridine has been found between mouse spleen lymphocytes, rabbit mesenteric lymphocytes, murine thymic lymphocytes and lymph node lymphocytes $(4,27,41,57)$. Electrical coupling between activated lymphocytes is blocked by an increase in intracellular $\mathrm{Ca}^{2+}$ concentration (9). In addition, dye coupling is reversibly blocked with octanol and prevented with synthetic peptides homologous to the extracellular loop 1 of Cxs (40), supporting the idea that electrical and metabolic coupling between activated lymphocytes occurs through gap junction channels. Consistently, mouse lymphocytes contain Cxs 37 and 43, but not Cxs 32, 33, 40 or 50, and upon treatment with Con-A both Cxs are translocated from the plasma membrane to cellular interphases (40). The latter event occurs without changes in $\mathrm{Cx}$ levels, suggesting that freshly isolated lymph node lymphocytes contain a preformed pool of Cxs. On the other hand, in vivo studies have shown that Cx43 expression by cells of mouse lymph nodes is induced by the administration of antigen (28). Moreover, in situ hybridization studies have shown that follicular dendritic cells and lymphocytes of germinal centers of other secondary lymphoid organs, such as human tonsil and spleen, also express $\mathrm{Cx} 43$ (28).

\section{Functional roles of gap junctions in cells of the immune system}

Although in some systems reduced gap junction communication is associated with an increase in tissue function, such as amylase secretion by the exocrine pancreas, more frequently it has been demonstrated to cause tissue disfunction (5). Inhibition of gap junctional communication of the rat gastric mucosa in combination with ischemia-reperfusion weakens the barrier function of the gastric mucosa and causes damage to the barrier function (58). Moreover, in longterm cultures of bone marrow the blockade of gap junctions with amphotericin retards stem cell growth (37). In addition, blockade of thymocyte gap junctions with octanol reduces the secretion of thymulin (13).

Antigen presentation leads to T-cell activation and proliferation, responses of lymphocytes that are cell-cell contact-dependent $(1,59)$, suggesting the involvement of cell-cell adhesion and/or gap junctional com- 
munication. The latter possibility was recently supported by the finding that synthetic peptides homologous to the extracellular loop 1 of Cxs prevent gap junction formation and drastically reduce the DNA replication of Con-A-treated mouse lymphocytes (40). Thus, gap junctional communication between proliferating lymphocytes might coordinate their metabolic and cytokine-induced responses to allow the appropriate timing of the specific immune response. Similarly, the blockade of leukemic cell differentiation has been associated with their intercellular coupling to stromal cells (34).

The innate and specific immune responses involve homo- and heterocellular contacts essential for their normal functioning. In many of those events, gap junctional communication is established, but their functional roles remain speculative except for few cases described above for which direct or indirect evidence has been provided. A putative gap junction role is synchronization of cellular events during the transmigration across cellular barriers. Supporting this view, gap junctions have been observed between metastase-forming leukemia cells and myeloid sinus endothelium (18), polymorphonuclear and endothelial cells (14) and macrophages and epithelial cells (24-26).

Clearly, further studies are needed to understand the role of gap junctions in different physiological and pathophysiological functions of the immune system.

\section{References}

1. Springer T (1990). Adhesion receptors of the immune system. Nature, 346: 425434.

2. Ben-Baruch A, Michiel DF \& Oppenheim JJ (1995). Signals and receptors involved in recruitment of inflammatory cells. J ournal of Biological Chemistry, 270: 1170311706.

3. Alves LA, Campos de Carvalho AC \& Savino W (1998). Gap junctions: a novel route for direct cell-cell communication in the immune system? Immunology Today, 19: $269-275$

4. Sáez J C, Araya R, Brañes MC, Concha M, Contreras JE, Eugenín EA, Martínez AD, Palisson F \& Sepúlveda MA (1999). Gap junctions in inflammatory responses: connexins, regulation and possible functional roles. In: Peracchia C (Editor), Gap J unctions - Molecular Basis of Cell Communication in Health and Diseases. Current Topics in Membranes. Academic Press, San Diego (in press).

5. Bruzzone R, White TH \& Paul DL (1996). Connections with connexins: the molecular basis of direct intercellular signaling. European J ournal of Biochemistry, 238: 1-27.

6. Phelan P, Bacon J P, Davies J A, Stebbings LA, Todman MG, Avery L, Baines RA, Barnes TM, Ford C, Hekimi S, Lee R, Shaw J E, Starich TA, Cutin KD, Sun YA \& Wyman RJ (1998). Innexins: a family of invertebrate gap-junction proteins. Trends in Genetics, 14: 348-349.

7. Hülser DF \& Peters J H (1971). Intercellular communication in phytohemagglutinininduced lymphocyte agglutinates. European J ournal of Immunology, 1: 494-495.

8. Oliveira-Castro GM, Barcinski MA \& Cukieman S (1973). Intercellular communication in stimulated human lymphocytes. J ournal of Immunology, 111: 16161619.

9. Oliveira-Castro GM \& Barcinski MA (1974). Calcium-induced uncoupling in communicating human lymphocytes. Biochimica et Biophysica Acta, 352: 338-343.

10. Levy J A, Weiss RM, Dirksen EL \& Rosen MR (1976). Possible communication between murine macrophages oriented in linear chains in tissue culture. Experimental Cell Research, 103: 375-385.

11. Porvaznik M \& MacVittie TJ (1979). Detection of gap junctions between the progeny of a canine macrophage colonyforming cell in vitro. J ournal of Cell Biology, 82: 555-564.

12. Krenács T \& Rosendaal M (1995). Immunohistologic detection of gap junctions in human lymphoid tissue: connexin43 in follicular dendritic and lymphoepithelial cells. J oumal of Histochemistry and Cytochemistry, 43: 1125-1137.

13. Alves LA, Campos de Carvalho AC, Lima EOC, Rocha e Souza CM, Dardene M, Spray DC \& Savino W (1995). Functional gap junctions in thymic epithelial cells are formed by connexin 43. European J ournal of Immunology, 2: 431-437.

14. J ara PI, Boric MP \& Sáez J C (1995). Leukocytes express connexin43 after activation with lipopolysaccharide and appear to form gap junctions with endothelial cells after ischemia-reperfusion. Proceedings of the National Academy of Sciences, USA, 92: 7011-7015.

15. Brañes $M C$, Contreras JE, Bono $M R \&$ Sáez JC (1997). Human polymorphonuclear cells express connexins and form homologous gap junctions. Molecular Biology of the Cell, 8: 417a (Abstract).

16. Martínez AD \& Sáez J C (1998). Rat microglia express connexins and upon activation form gap junctions. Molecular Biology of the Cell, 9: 326a (Abstract).

17. Afonso A, Silva J, Lousada S, Ellis $A E \&$ Silva MT (1998). Uptake of neutrophils and neutrophilic components by macrophages in the inflamed peritoneal cavity of rainbow trout (Oncorhynchus mykiss). Fish and Shellfish Immunology, 8: 319338.

18. De Bruyn PPH, Cho $Y \&$ Michelson $S$ (1989). Endothelial attachment and plasmalemmal apposition in the transcellular movement of intravascular leukemic cells entering the myeloid parenchyma. American J ournal of Anatomy, 186: 115-126.

19. Concha M, Figueroa CD \& Caorsi I (1988). Ultrastructural characteristics of the contact zones between Langerhans cells and 
lymphocytes. J ournal of Pathology, 156: 29-36.

20. Concha M, Vidal A, Garcés G, Figueroa CD \& Caorsi I (1993). Physical interaction between Langerhans cells and T-lymphocytes during antigen presentation in vitro. J ournal of Investigative Dermatology, 100: 429-434.

21. Brand CU, Hunziker T, Schaffner T, Limat A, Gerber HA \& Braathen LR (1995). Activated immunocompetent cells in human skin lymph-derived from irritant contact dermatitis: an immunomorphologic study. British J ournal of Dermatology, 132: 3945.

22. Raine CS, Cannella B, Dujivestijn AM \& Cross AH (1990). Homing to central nervous system vasculature by antigen-specific lymphocytes. II. Lymphocyte/endothelial cell adhesion during the initial stages of autoimmune demyelination. Laboratory Investigation, 63: 476-479.

23. Guinan S, Smith BR, Davies PF \& Pober J S (1988). Cytoplasmic transfer between endothelium and lymphocytes: quantitation by flow cytometry. American J oumal of Pathology, 132: 406-409.

24. El-Sabban ME, Martin CA \& Homaidan FR (1998). Signaling between immune cells and intestinal epithelial cells in vitro. In: Werner R (Editor), Gap J unctions. IOS Press, The Netherlands, 178-182.

25. Martin CA, Homaidan FR, Palaia T, Burakoff R \& El-Sabban ME (1998). Gap junctional communication between murine macrophages and intestinal epithelial cell lines. Cell Adhesion and Communication, 5: 437-449.

26. Martin CA, El-Sabban ME, Zhao L, Burakoff R \& Homaidan FR (1998). Adhesion and cytosolic dye transfer between macrophages and intestinal epithelial cells. Cell Adhesion and Communication, 5: 83-95.

27. Sellin D, Wallach DFH \& Fischer H (1971). Intercellular communication in cell-mediated cytotoxicity fluorescein transfer between $\mathrm{H}-2^{\mathrm{d}}$ target cells and $\mathrm{H}-2^{\mathrm{b}}$ lymphocytes in vitro. European J ournal of Immunology, 4: 189-193.

28. Krenács $T$, Van Dartel $M$, Lindhout $E$ \& Rosendaal M (1997). Direct cell/cell communication in the lymphoid germinal center: connexin43 gap junctions functionally couple follicular dendritic cells to each other and to B lymphocytes. European J oumal of Immunology, 27: 1489-1497.

29. Watanabe $Y$ (1985). Fine structure of bone marrow stroma. Acta Haematologica J aponica, 48: 1688-1695.

30. Umezawa A, Harigaya $\mathrm{K}$, Abe $\mathrm{H}$ \&
Watanabe Y (1990). Gap-junctional communication of bone marrow cells is resistant to irradiation in vitro. Experimental Hematology, 8: 1002-1007.

31. Umezawa A \& Hata J (1992). Expression of gap-junctional protein (connexin43 or alpha 1 gap junction) is down regulated at the transcriptional level during adipocyte differentiation of $\mathrm{H}-\mathrm{I} / \mathrm{A}$ marrow stromal cells. Cell Structure and Function, 17: 177184.

32. Ohkawa $\mathrm{H} \&$ Harigaya $\mathrm{K}$ (1987). Effect of direct cell-cell interaction between the KM-102 clonal human marrow stromal cell line and the HL-60 myeloid leukemic cell line on the differentiation and proliferation of the HL-60 line. Cancer Research, 47: 2879-2882.

33. Allen T \& Dexter TM (1984). The essential cells of the hematopoietic microenvironment. Experimental Hematology, 12: 517521.

34. Weber MC \& Tykocinski ML (1994). Bone marrow stromal cell blockade of human leukemic cell differentiation. Blood, 83: 2221-2229.

35. Rosendaal M, Gregan A \& Green CR (1991). Direct cell-cell communication in the blood-forming system. Tissue and Cell, 23: 457-470.

36. Rosendaal $M$, Green $C R$, Rahman $A$ \& Morgan $D$ (1994). Up-regulation of the connexin43+ gap junction network in haemopoietic tissue before the growth of stem cells. J ournal of Cell Science, 107: 29-37.

37. Krenács $T \&$ Rosendaal M (1998). Connexin43 gap junctions in nomal, regenerating, and cultured mouse bone marrow and in human leukemias. Their possible involvement in blood formation. American J ournal of Pathology, 152: 993-1004.

38. Dorshkind K, Green L, Godwin A \& Fletcher WH (1993). Connexin-43-type gap junctions mediate communication between bone marrow stromal cells. Blood, 82: 38-45.

39. Campbell FR (1982). Intercellular contacts between migrating blood cells and cells of the sinusoidal wall of the bone marrow. An ultrastructural study using tannic acid. Anatomical Record, 20: 365-374.

40. Sáez J C, Sepúlveda MA, Araya R, Sáez CG \& Palisson F (1998). Concanavalin Aactivated lymphocytes form gap junctions that increase their rate of DNA replication. In: Werner R (Editor), Gap J unctions. IOS Press, Amsterdam, 372-376.

41. Carolan E \& Pitts J D (1986). Some murine thymic lymphocytes can form gap junctions. Immunological Letters, 13: 255-260.
42. Hu VW \& Xie HQ (1994). Interleukin-1 $\alpha$ suppresses gap junction-mediated intercellular communication in human endothelial cells. Experimental Cell Research, 213: 218-223.

43. van Rijen HV, van Kempel MJ \& J ongsma HJ (1998). Tumor necrosis alpha alters the expression of connexin43, connexin40, and connexin37 in human umbilical vein endothelial cells. Cytokine, 10: 258264.

44. Hu J \& Cotgreave IA (1997). Differential regulation of gap junctions by proinflammatory mediators in vitro. J oumal of Clinical Investigation, 99: 2312-2316.

45. Brañes MC, Martínez AD, Recabarren $M$, Couraud PO \& Sáez J C (1998). Regulation of gap junctions formed between endothelial cells (ECs) and ECs and astrocytes. Molecular Biology of the Cell, 9: 325a (Abstract).

46. Little TL, Xia J \& Duling BR (1995). Dye tracers define differential endothelial and smooth muscle coupling pattems within the arteriolar wall. Circulation Research, 76: 498-504.

47. Boric MP, Roth $A, J$ ara $P \&$ Sáez JC (1997). Gap junction between leukocytes and endothelium: expression of connexin43 in adherent or activated cells. In: Latorre R \& Sáez J C (Editors), From Ion Channels to Cell-to-Cell Conversations. Plenum Press, New York, 249-366.

48. Beyer EC \& Steinberg TH (1991). Evidence that gap junction protein connexin43 is the ATP-induced pore of mouse macrophages. J oumal of Biological Chemistry, 266: 7971-7974.

49. Polacek D, Lal L, Volin MV \& Davies PF (1993). Gap junctional communication between vascular cells. Induction of connexin43 messenger RNA in macrophage foam cells of atherosclerotic lesions. American J ournal of Pathology, 142: 593606.

50. Hillis GS, Duthie LA, Brown PA, Simpson J G, MacLeod AM \& Haites NE (1997). Upregulation and co-localization of connexin43 and cellular adhesion molecules in inflammatory renal disease. J ournal of Pathology, 18: 373-379.

51. Sáez CG, Eugenín E, Hertzberg EL \& Sáez JC (1997). Regulation of gap junction in rat liver during acute and chronic $\mathrm{CCl}_{4-}$ induced liver injury. In: Latorre $\mathrm{R} \&$ Sáez J C (Editors), From Ion Channels to Cell-toCell Conversations. Plenum Press, New York, 367-380.

52. Navab M, Liao F, Hough GP, Ross LA, Van Lenten BJ, Rajavashisth TB, Lusis AJ , Lacks H, Drinkwater DC \& Fogelman AM 
(1991). Interaction of monocytes with cocultures of human aortic wall cells involves interleukins 1 and 6 with marked increases in connexin43 message. J ournal of Clinical Investigation, 8: 1763-1772.

53. Vliagotis $\mathrm{H}$, Hutson AM, Mahmudi-Azer $\mathrm{S}$, Kim H, Rumsaeng V, Oh CK, Moqbel R \& Metcalfe DD (1999). Mast cells express connexins on their cytoplasmic membrane. J oumal of Allergy and Clinical Immunology, 103: 656-662.

54. Alves LA, Countinho-Silva R, Persechini PM, Spray DC, Savino W \& Campos de Carvalho AC (1996). Are there functional gap junctions or junctional hemichannels in macrophages? Blood, 8: 328-334.

55. Churchill D, Coodin S, Shivers RR \& Caveney S (1993). Rapid de novo formation of gap junctions between insect hemocytes in vitro: a freeze-fracture, dye transfer and patch clamp study. J ournal of Cell Science, 104: 763-772.

56. Lukacs NW, Strieter RM, Evanoff HL, Burdick MD \& Kunkel SL (1994). VCAM-1 influences lymphocyte proliferation and cytokine production during mixed lymphocyte responses. Cellular Immunology, 154: 88-98.

57. Sellin D, Wallach DFH, Weltzein HV, Esch K, Sprenger E \& Fisher H (1974). Intercel- lular communication between lymphocytes in vitro. Fluorescein-permeable junctions, their enhancement by lysolecithin and their reduction by synthetic immunosuppressive lysolecithin analogue. European J ournal of Immunology, 4: 189-193.

58. Iwata $F$, J oh $T$, Ueda $F$, Yokoyama $Y$ \& Itoh M (1998). Role of gap junctions in inhibiting ischemia-reperfusion injury of rat gastric mucosa. American J oumal of Physiology, 275: G883-G888.

59. Peters J H (1972). Contact cooperation in stimulated lymphocytes. Experimental Cell Research, 74: 179-186. 